\title{
Allergic diseases of the skin and drug allergies - 2006. Cord blood 25-hydroxyvitamin D3 and allergic disease during infancy
}

\author{
Anderson Phillip Jones ${ }^{1 *}$, Debra Palmer ${ }^{1}$, Guicheng Zhang ${ }^{1}$, Susan Prescott ${ }^{2}$ \\ From 2nd WAO International Scientific Conference (WISC 2012) \\ Hyderabad, India. 6-9 December 2012
}

\section{Background}

There has been growing interest in vitamin D insufficiency as a predisposing factor for allergy development based on immunoregulatory properties and epidemiological studies. The aim of this study was to investigate the association between vitamin $\mathrm{D}$ exposure in utero and allergic outcomes in the first year of life.

\section{Methods}

Cord blood (CB) vitamin D was measured in 231 high risk infants from an Australian prospective birth cohort. CB 25(OH)D3 concentration was analysed in relation to maternal vitamin $D$ intake and the development of infant eczema, allergen sensitization and IgE-mediated food allergy.

\section{Results}

Maternal intake of supplemental vitamin D was significantly correlated with CB $25(\mathrm{OH}) \mathrm{D} 3$ concentration (rho $=0.244, p=0.003$ ) while dietary vitamin $\mathrm{D}$ did not influence $\mathrm{CB}$ levels. There was significant seasonal variation in $\mathrm{CB} 25(\mathrm{OH}) \mathrm{D} 3$ concentration suggesting that sunlight exposure was an important determinant. Lower CB vitamin D status was observed in infants that developed eczema $(p=0.018)$, and eczema was significantly more likely in those with concentrations $<50 \mathrm{nmol} / \mathrm{L}$ compared with $>75 \mathrm{nmol} / \mathrm{L}$ (OR 2.66; 95\% CI $1.24-$ 5.72; $p=0.012$ ). This association remained significant after adjustment for multiple confounding factors. The associations between $\mathrm{CB} 25(\mathrm{OH}) \mathrm{D} 3$ concentration and allergen sensitization, IgE-mediated food allergy and eczema severity (SCORAD) were not significant.

${ }^{1}$ School of Paediatrics and Child Health, University of Western Australia, Perth, Australia

Full list of author information is available at the end of the article

\section{Conclusions}

Reduced vitamin D status in pregnancy may be a risk factor for the development of eczema in the first year of life, reinforcing the need to explore the role of vitamin $\mathrm{D}$ exposure during development for disease prevention.

\section{Author details}

${ }^{1}$ School of Paediatrics and Child Health, University of Western Australia, Perth, Australia. ${ }^{2}$ Immunology, Princess Margaret Hospital, Australia.

Published: 23 April 2013

doi:10.1186/1939-4551-6-S1-P96

Cite this article as: Jones et al:: Allergic diseases of the skin and drug allergies - 2006. Cord blood 25-hydroxyvitamin D3 and allergic disease during infancy. World Allergy Organization Journal 2013 6(Suppl 1):P96.

Submit your next manuscript to BioMed Central and take full advantage of:

- Convenient online submission

- Thorough peer review

- No space constraints or color figure charges

- Immediate publication on acceptance

- Inclusion in PubMed, CAS, Scopus and Google Scholar

- Research which is freely available for redistribution

\section{() Biomed Central}

(c) 2013 Jones et al; licensee BioMed Central Ltd. This is an Open Access article distributed under the terms of the Creative Commons Attribution License (http://creativecommons.org/licenses/by/2.0), which permits unrestricted use, distribution, and reproduction in any medium, provided the original work is properly cited. 